Proceedings

\title{
Deposited Particulate Matter Enrichment in Heavy Metals and Related Health Risk: A Case Study of Krakow, Poland +
}

\author{
Agnieszka Gruszecka-Kosowska \\ Department of Environmental Protection, Faculty of Geology, Geophysics, and Environmental Protection, \\ AGH University of Science and Technology, Al. Mickiewicza 30, 30-059 Kraków, Poland; \\ agnieszka.gruszecka@agh.edu.pl \\ + Presented at the 2nd International Electronic Conference on Environmental Health Sciences, \\ 4-29 November 2019; Available online: https://iecehs-2.sciforum.net/.
}

Published: 1 November 2019

\begin{abstract}
The aim of these investigations was to determine the impact of heavy metals bound with deposited particulate matter (PM) on contamination degree and related toxicological effects by calculating enrichment indices, namely, the geo-accumulation index (Igeo), contamination factor $(\mathrm{CF})$, and enrichment factor (EF), as well as the ecological risk index (ERI) and modified hazard quotient (mHQ). Calculations were made based on the selected element concentrations determined in deposited PM samples in Krakow. The results of the investigations revealed that deposited PM was enriched in heavy metals. As Igeo provides information on the level of metal accumulation, it was found that deposited PM was practically uncontaminated with $\mathrm{Be}, \mathrm{Cd}$, and $\mathrm{Tl}$ (class 0 ) but heavily to extremely contaminated (class 5) with $\mathrm{Co}$ and Sn and extremely contaminated (class 6) with $\mathrm{As}, \mathrm{Ba}, \mathrm{Cr}, \mathrm{Cu}, \mathrm{Li}, \mathrm{Mn}, \mathrm{Ni}, \mathrm{Pb}, \mathrm{Sr}, \mathrm{Ti}, \mathrm{V}$, and $\mathrm{Zn}$. On the other hand, the calculated values of $\mathrm{CF}$ revealed very high contamination of deposited $\mathrm{PM}$ with $\mathrm{Cd}$ and $\mathrm{Zn}$, considerable contamination with $\mathrm{Sn}, \mathrm{Pb}$, and $\mathrm{As}$, and moderate contamination with $\mathrm{Cu}$ and Li. Values of calculated EF revealed that among the investigated elements, only $\mathrm{Zn}$ originated from anthropogenic sources. For $\mathrm{Cd}$, a small influence of anthropogenic sources was observed. For $\mathrm{Pb}$ and $\mathrm{Sn}$, non-crustal sources of emission were expected. The calculated ERI values indicated potential ecological risk levels that were very high for $\mathrm{Cd}$ and considerable for $\mathrm{Zn}$, as well as low potential ecological risk for As, Co, $\mathrm{Cr}, \mathrm{Cu}, \mathrm{Ni}, \mathrm{Pb}$, and $\mathrm{Tl}$. Moreover, the calculated $\mathrm{mHQ}$ values of severity of contamination were extreme for $\mathrm{Zn}$, considerable for $\mathrm{Cr}$, and moderate for $\mathrm{As}, \mathrm{Cu}$, and $\mathrm{Pb}$. The analysis revealed that the impact of atmospheric and re-suspended PM on inhabitants constitutes a complex effect of a mixture of heavy metals simultaneously affecting human health.
\end{abstract}

Keywords: air quality; particulate matter; heavy metals; contamination factors; health risk

\section{Introduction}

The air quality is of utmost importance due to its direct effect on human health. For many years, Krakow has been an example of a city with constant poor or even very poor air quality [1]. Analyzing the results of the ambient air quality monitoring network in Krakow, operated by the Regional Environmental Protection Inspectorate in Krakow (WIOŚ), it was observed that particulate matter (PM) is the key air pollutant [2-4]. Moreover, PM particles bind other contaminants, especially heavy metals, that, alongside PM, cause negative health effects after entering the body through inhalation, digestion, or dermal contact. Heavy metals cause many negative health effects associated with renal, cardiovascular, blood, nervous, or bone systems [5]. The enrichment indices are widely used to 
provide information on element contamination in the investigated component in relation to an uncontaminated medium, i.e., Earth's crust or uncontaminated/natural soils. These indices have recently been used in air pollution research, and permissible contents of heavy metals have been established for just a few of them. Taking the above under consideration, the aim of the investigations presented herein was to determine the impact of heavy metals bound with deposited PM on contamination degree and related toxicological effects by calculating enrichment indices, namely, the geo-accumulation index (Igeo), contamination factor (CF), and enrichment factor (EF), as well as the ecological risk index (ERI) and modified hazard quotient (mHQ).

\section{Material and Methods}

Deposited PM samples were investigated from 2014 to 2016 as described in detail in GruszeckaKosowska and Wdowin [6]. Heavy metal concentrations were analyzed using Inductively Coupled Plasma Mass Spectroscopy (ICP-MS) after digestion of samples in aqua regia and mineralization for 2 $\mathrm{h}$ in $130{ }^{\circ} \mathrm{C}$ in an SCP Science DigiPREP HT High Temperature Digestion System (SCP Science, Quebec, Canada) according to the USEPA 3050B extraction method [7]. As element contents in PM for the calculation of enrichment indices, mean values of heavy metal concentrations in deposited PM from the investigations of Gruszecka-Kosowska and Wdowin [6] were taken (Table 1).

Table 1. Heavy metal concentrations in deposited particulate matter (PM) samples in Krakow (modified from [6]).

\begin{tabular}{cc}
\hline Element & Mean value $(\mathbf{m g} / \mathbf{k g})$ \\
\hline $\mathrm{As}$ & 14.7 \\
$\mathrm{Ba}$ & 111.5 \\
$\mathrm{Be}$ & 0.54 \\
$\mathrm{Cd}$ & 1.2 \\
$\mathrm{Co}$ & 2.35 \\
$\mathrm{Cr}$ & 90 \\
$\mathrm{Cu}$ & 74.5 \\
$\mathrm{Li}$ & 21.1 \\
$\mathrm{Mn}$ & 623.5 \\
$\mathrm{Ni}$ & 24.5 \\
$\mathrm{~Pb}$ & 85.5 \\
$\mathrm{Sn}$ & 12.5 \\
$\mathrm{Sr}$ & 140.5 \\
$\mathrm{Ti}$ & 223 \\
$\mathrm{Tl}$ & 0.26 \\
$\mathrm{~V}$ & 30 \\
$\mathrm{Zn}$ & 5820 \\
\hline
\end{tabular}

A detailed description of the calculated enrichment indices in this study is given in Table 2. The geo-accumulation index (Igeo) provides information on the accumulation of heavy metals in relation to the background value. Contamination factor (CF) determines the contamination of heavy metals in reference to the background value as well. As the background values for calculating Igeo and CF values, local geochemical values [8] were taken. Enrichment factor (EF) describes enrichment with heavy metals in relation to elements with a low variability of occurrence; here, Fe was chosen, and as background values both concentrations from the upper continental crust [9] and local geochemical values [8] were used. For determination of ecological risk, the ecological risk index (ERI) and modified hazard quotient (MHQ) were used, which enabled the assessment of contamination by comparing the metal concentration with the synoptic adverse ecological effect distributions for slightly differing threshold levels [10]. 


\section{Results and Discussion}

The calculated values of the enrichment indices used and the corresponding classes are presented in Table 3. The results of the investigations revealed that deposited PM was enriched in heavy metals. Based on the calculated Igeo values, in the investigated deposited PM samples, accumulation of the analyzed heavy metals was the highest for $\mathrm{As}, \mathrm{Ba}, \mathrm{Cr}, \mathrm{Cu}, \mathrm{Li}, \mathrm{Mn}, \mathrm{Ni}, \mathrm{Pb}, \mathrm{Sr}, \mathrm{Ti}$, $\mathrm{V}$, and $\mathrm{Zn}$ (class 6), as well as for $\mathrm{Co}$ and $\mathrm{Sn}$ (class 5). Instead, for $\mathrm{Be}, \mathrm{Cd}$, and $\mathrm{Tl}$, the calculated Igeo values indicated no accumulation (class 0 ). On the other hand, the calculated CF values revealed very high contamination of the analyzed deposited PM samples with $\mathrm{Cd}$ and $\mathrm{Zn}$, considerable contamination with $\mathrm{As}, \mathrm{Pb}$, and $\mathrm{Sn}$, and moderate contamination with $\mathrm{Cu}$ and $\mathrm{Li}$. For the other investigated elements, $\mathrm{CF}$ values indicated low contamination. Also, the EF values (presented here as the mean values of EF calculated for different background values as described above) indicated that the analyzed deposited PM samples were extremely severely enriched with $\mathrm{Zn}$, moderately severely enriched with Sn, and severely enriched with Cd. Minor enrichment of PM was observed for $\mathrm{Cu}$. For the other investigated elements, EF values indicated no enrichment. The calculated EF values indicated anthropogenic sources ( $\mathrm{EF}>30$ ) of elements only in the case of $\mathrm{Zn}$. For Cd, a small proportion of anthropogenic sources was determined. $\mathrm{For} \mathrm{Pb}$ and $\mathrm{Sn}$, non-crustal sources of elements were revealed. Crustal sources of elements were defined for $\mathrm{As}, \mathrm{Ba}, \mathrm{Be}, \mathrm{Co}, \mathrm{Cr}, \mathrm{Cu}, \mathrm{Li}, \mathrm{Mn}, \mathrm{Ni}, \mathrm{Sr}, \mathrm{Ti}$, $\mathrm{Tl}$, and $\mathrm{V}$.

The calculated values of ERI indicated very high ecological risk of the analyzed deposited PM samples only in the case of $\mathrm{Cd}$ and considerable ecological risk for $\mathrm{Zn}$. For $\mathrm{As}, \mathrm{Co}, \mathrm{Cr}, \mathrm{Cu}, \mathrm{Ni}, \mathrm{Pb}$, and $\mathrm{Tl}$, low ecological risk was determined. For $\mathrm{Ba}, \mathrm{Be}, \mathrm{Li}, \mathrm{Mn}, \mathrm{Sn}, \mathrm{Sr}, \mathrm{Ti}$, and $\mathrm{V}$, ecological risk values were not defined due to the lack of adverse ecological effect values. Ecological risk defined based on the $\mathrm{mHQ}$ index revealed extreme severity of contamination of the deposited PM samples with $\mathrm{Zn}$ and considerable severity of contamination with $\mathrm{Cr}$. For $\mathrm{As}, \mathrm{Cu}$, and $\mathrm{Pb}$, moderate-severity contamination was indicated, while for $\mathrm{Cd}$ and $\mathrm{Ni}$, low-severity contamination was indicated. Values of mHQ were not defined for $\mathrm{Ba}, \mathrm{Be}, \mathrm{Co}, \mathrm{Li}, \mathrm{Mn}, \mathrm{Sn}, \mathrm{Sr}, \mathrm{Ti}, \mathrm{Tl}$, and $\mathrm{V}$ due to the lack of adverse ecological effect values. 
Table 2. Description of the enrichment indices used in the study.

\begin{tabular}{|c|c|c|c|c|c|}
\hline Enrichment factor & Formulas & Explanation & Limit values & Classification & References \\
\hline $\begin{array}{l}\text { Geo-accumulation index } \\
\text { Igeo }\end{array}$ & $\mathrm{Igeo}_{\mathrm{ge}}=\log _{2}\left(\mathrm{C}_{\mathrm{i}} / 1.5^{*} \mathrm{~B}_{\mathrm{n}}\right)$ & $\begin{array}{c}\mathrm{C}_{\mathrm{i}}-\text { content of element in } \\
\text { PM; } \mathrm{B}_{\mathrm{n}}-\text { background value; } \\
1.5-\text { constant }\end{array}$ & $\begin{array}{c}\mathrm{I}_{\text {geo }} \leq 0 \\
0 \leq \mathrm{I}_{\text {geo }}<1 \\
1 \leq \mathrm{I}_{\text {geo }}<2 \\
2 \leq \mathrm{I}_{\text {geo }}<3 \\
3 \leq \mathrm{I}_{\text {geo }}<4 \\
4 \leq \mathrm{I}_{\text {geo }}<5 \\
5 \leq \mathrm{I}_{\text {geo }}\end{array}$ & $\begin{array}{c}\text { Class } 0 \text { - practically uncontaminated } \\
\text { Class } 1 \text { - uncontaminated to moderately } \\
\text { contaminated } \\
\text { Class } 2-\text { moderately contaminated } \\
\text { Class } 3 \text { - moderately to heavily contaminated } \\
\text { Class } 4 \text { - heavily contaminated } \\
\text { Class } 5 \text { - heavily to extremely contaminated } \\
\text { Class } 6 \text { - extremely contaminated }\end{array}$ & {$[11,12]$} \\
\hline $\begin{array}{l}\text { Contamination factor } \\
\qquad \mathrm{CF}\end{array}$ & $\mathrm{CF}=\mathrm{Cm}_{\mathrm{i}} / \mathrm{C}_{\mathrm{ref}}$ & $\begin{array}{l}\mathrm{Cm} \text { - mean element } \\
\text { concentration in } \mathrm{PM} ; \mathrm{C}_{\mathrm{ref}}- \\
\text { reference value of element }\end{array}$ & $\begin{array}{c}\mathrm{CF}<1 \\
1 \leq \mathrm{CF}<3 \\
3 \leq \mathrm{CF}<6 \\
6 \leq \mathrm{CF}\end{array}$ & $\begin{array}{c}\text { low contamination } \\
\text { moderate contamination } \\
\text { considerable contamination } \\
\text { very high contamination } \\
\end{array}$ & {$[13,14]$} \\
\hline $\begin{array}{l}\text { Enrichment factor } \\
\text { EF }\end{array}$ & $\mathrm{EF}=\left(\mathrm{C}_{\mathrm{i}} / \mathrm{C}_{\mathrm{ref}}\right) /\left(\mathrm{Bi}_{\mathrm{i}} / \mathrm{B}_{\mathrm{ref}}\right)$ & $\begin{array}{l}\mathrm{C}_{\mathrm{i}}-\text { content of element in } \\
\mathrm{PM} \text {; } \mathrm{C}_{\text {ref }}-\text { content of Fe in } \\
\text { sample; } \mathrm{B}_{\mathrm{i}}-\text { reference } \\
\text { content of single element; } \\
\text { Bref - reference content of Fe }\end{array}$ & $\begin{array}{c}\mathrm{EF} \leq 1 \\
1<\mathrm{EF} \leq 3 \\
3<\mathrm{EF} \leq 5 \\
5<\mathrm{EF} \leq 10 \\
10<\mathrm{EF} \leq 25 \\
25<\mathrm{EF} \leq 50 \\
\mathrm{EF}>50\end{array}$ & $\begin{array}{c}\text { no enrichment } \\
\text { minor enrichment } \\
\text { moderate enrichment } \\
\text { moderately severe enrichment } \\
\text { severe enrichment } \\
\text { very severe enrichment } \\
\text { extremely severe enrichment }\end{array}$ & {$[15,16]$} \\
\hline $\begin{array}{c}\text { Ecological risk index } \\
\text { ERI }\end{array}$ & $\mathrm{ERI}=\operatorname{Tr}_{\mathrm{i}} \times \mathrm{CF}_{\mathrm{i}}$ & $\begin{array}{l}\mathrm{Tr} \text { - toxicity response } \\
\text { coefficient of single } \\
\text { element; } \mathrm{CF}_{\mathrm{i}}- \\
\text { contamination factor of } \\
\text { single element } \\
\end{array}$ & $\begin{array}{c}\mathrm{ERI}<40 \\
40 \leq \mathrm{ERI}<80 \\
80 \leq \mathrm{ERI}<160 \\
160 \leq \mathrm{ERI}<320 \\
320 \leq \mathrm{ERI} \\
\end{array}$ & $\begin{array}{c}\text { low potential ecological risk } \\
\text { moderate potential ecological risk } \\
\text { considerable potential ecological risk } \\
\text { high potential ecological risk } \\
\text { very high potential ecological risk } \\
\end{array}$ & {$[13,17-20]$} \\
\hline $\begin{array}{l}\text { Modified hazard quotient } \\
\text { mHQ }\end{array}$ & $\begin{array}{c}\mathrm{mHQ}=\left[\mathrm{Ci}\left(\frac{1}{\mathrm{TELi}}+\frac{1}{\mathrm{PELi}}+\right.\right. \\
\left.\left.\frac{1}{\mathrm{SELi}}\right)\right]^{2}\end{array}$ & $\begin{array}{l}\text { Ci-concentration of } \\
\text { element in PM; TEL- } \\
\text { threshold effect level; } \\
\text { PEL - probable effect level; } \\
\text { SEL - severe effect level for } \\
\quad \text { single element }\end{array}$ & $\begin{array}{c}\mathrm{mHQ}<0.5 \\
0.5<\mathrm{mHQ}<1.0 \\
1.0<\mathrm{mHQ}<1.5 \\
1.5<\mathrm{mHQ}<2.0 \\
2.0<\mathrm{mHQ}<2.5 \\
2.5<\mathrm{mHQ}<3.0 \\
3.0<\mathrm{mHQ}<3.5 \\
\mathrm{mHQ}>3.5 \\
\end{array}$ & $\begin{array}{c}\text { nil to very low severity of contamination } \\
\text { very low severity of contamination } \\
\text { low severity of contamination } \\
\text { moderate severity of contamination } \\
\text { considerable severity of contamination } \\
\text { high severity of contamination } \\
\text { very high severity of contamination } \\
\text { extreme severity of contamination } \\
\end{array}$ & {$[10,21]$} \\
\hline
\end{tabular}


Table 3. Enrichment index classes for deposited PM in Krakow.

\begin{tabular}{|c|c|c|c|c|c|c|c|c|c|c|}
\hline \multirow{2}{*}{ Element } & \multicolumn{2}{|c|}{ Igeo } & \multicolumn{2}{|r|}{ CF } & \multicolumn{2}{|r|}{ EF (mean) } & \multicolumn{2}{|r|}{ ERI } & \multicolumn{2}{|r|}{ mHQ } \\
\hline & value & class & value & class & value & class & value & class & value & class \\
\hline As & 5.6 & 6 & 3.06 & considerable & 2.63 & minor & 30.6 & low & 1.90 & moderate severity \\
\hline $\mathbf{B a}$ & 15.5 & 6 & 0.18 & low & 0.15 & no & - & - & - & - \\
\hline $\mathrm{Be}$ & -0.4 & 0 & 0.26 & low & 0.22 & no & - & - & - & - \\
\hline Cd & -3.8 & 0 & 13.3 & very high & 11.44 & severe & 400 & very high & 1.24 & low severity \\
\hline Co & 4.8 & 5 & 0.14 & low & 0.12 & no & 0.7 & low & - & - \\
\hline $\mathrm{Cr}$ & 12.4 & 6 & 0.98 & low & 0.84 & no & 2.0 & low & 2.12 & considerable severity \\
\hline $\mathrm{Cu}$ & 10.4 & 6 & 2.66 & moderate & 2.28 & minor & 13.3 & low & 1.57 & moderate severity \\
\hline $\mathbf{L i}$ & 8.2 & 6 & 1.00 & moderate & 0.86 & no & - & - & - & - \\
\hline Mn & 18.3 & 6 & 0.81 & low & 0.69 & no & - & - & - & - \\
\hline $\mathrm{Ni}$ & 9.6 & 6 & 0.52 & low & 0.45 & no & 2.6 & low & 1.18 & low severity \\
\hline $\mathbf{P b}$ & 9.9 & 6 & 5.03 & considerable & 4.32 & moderate & 25.1 & low & 1.86 & moderate severity \\
\hline Sn & 4.1 & 5 & 5.95 & considerable & 5.11 & moderately severe & - & - & - & - \\
\hline Sr & 14.9 & 6 & 0.44 & low & 0.38 & no & - & - & - & - \\
\hline $\mathbf{T i}$ & 19.6 & 6 & 0.04 & low & 0.03 & no & - & - & - & - \\
\hline $\mathrm{Tl}$ & -2.7 & 0 & 0.29 & low & 0.25 & no & 2.9 & low & - & - \\
\hline $\mathbf{V}$ & 10.9 & 6 & 0.31 & low & 0.27 & no & - & - & - & - \\
\hline Zn & 18.0 & 6 & 86.87 & very high & 74.56 & extremely severe & 86.9 & considerable & 36.45 & extreme severity \\
\hline
\end{tabular}




\section{Conclusions}

The studies revealed enrichment of the analyzed deposited PM samples with heavy metals. Extreme contamination (class 6) was observed for $\mathrm{As}, \mathrm{Ba}, \mathrm{Cr}, \mathrm{Cu}, \mathrm{Li}, \mathrm{Mn}, \mathrm{Ni}, \mathrm{Pb}, \mathrm{Sr}, \mathrm{Ti}, \mathrm{V}$, and $\mathrm{Zn}$, as well as heavy to extreme contamination (class 5) for $\mathrm{Co}$ and $\mathrm{Sn}$ according to the Igeo index. Very high contamination of deposited PM with $\mathrm{Cd}$ and $\mathrm{Zn}$, considerable contamination with $\mathrm{Sn}, \mathrm{Pb}$, and $\mathrm{As}$, and moderate contamination with $\mathrm{Cu}$ and $\mathrm{Li}$ were indicated according to the $\mathrm{CF}$ values. The $\mathrm{EF}$ values indicated extremely severe enrichment with $\mathrm{Zn}$, moderately severe enrichment with $\mathrm{Sn}$, severe enrichment with $\mathrm{Cd}$, and minor enrichment with $\mathrm{Cu}$. The calculated values of EF revealed that among the investigated elements, only $\mathrm{Zn}$ originated from anthropogenic sources. For $\mathrm{Cd}$, a small influence of anthropogenic sources was observed. For $\mathrm{Pb}$ and $\mathrm{Sn}$, non-crustal sources of emission were expected. The potential ecological risk was determined as very high for $\mathrm{Cd}$, considerable for $\mathrm{Zn}$, and low for $\mathrm{As}, \mathrm{Co}, \mathrm{Cr}, \mathrm{Cu}, \mathrm{Ni}, \mathrm{Pb}$, and $\mathrm{Tl}$ according to the calculated ERI values. Moreover, the severity of contamination as indicated by calculated $\mathrm{mHQ}$ values was extreme for $\mathrm{Zn}$, considerable for $\mathrm{Cr}$, and moderate for $\mathrm{As}, \mathrm{Cu}$, and $\mathrm{Pb}$. The analysis confirmed that atmospheric and re-suspended $\mathrm{PM}$ has a comprehensive health impact.

Funding: This research received no external funding.

Conflicts of Interest: The author declares no conflict of interest.

\section{References}

1. European Environment Agency. Air Quality in Europe-2018 Report; EEA Report No 12/2018; Publications Office of the European Union: Luxembourg, Luxembourg, 2018.

2. Bokwa, A. Environmental impact of long-term air pollution changes in Krakow, Poland. Polish J. Environ. Stud. 2008, 5, 673-686.

3. Choi. H.; Melly, S.; Spengler, J. Intraurban and longitudinal variability of classical pollutants in Kraków, Poland, 2000-2010. Int. J. Environ. Res. Public Health 2015, 12, 4967-4991.

4. Gruszecka-Kosowska, A. Assessment of the Krakow inhabitants' health risk caused by the exposure to inhalation of outdoor air contaminants. Stoch. Environ. Res. Risk Assess. 2018, 32, 485-499.

5. Bini, C., Bech, J. PHEs, environment and human health. Potentially harmful elements in the environment and the impact on human health; Springer: Heidelberg, Germany, 2014.

6. Gruszecka-Kosowska, A.; Wdowin, M. The mineralogy, geochemistry and health risk assessment of deposited particulate matter (PM) in Kraków, Poland. Geol. Geophys. Environ. 2016, 42, 429.

7. Method 3050B: Acid Digestion of Sediments, Sludges, and Soils; Revision 2. US Environmental Protection Agency: Washington, DC, USA, 1996.

8. Kabata-Pendias, A. Trace Elements in Soils and Plants, 4th ed.; CRC Press, Taylor \&Francis Group: Boca Raton, FL, USA, 2011.

9. Rudnick, R.; Gao, S. Composition of the Continental Crust. Treatise Geochem. 2014, 4, 1-51.

10. Benson, N.U.; Adedapo, A.E.; Fred-Ahmadu, O.H.; Williams, A.; Udosen, E.D.; Ayejuyo, O.O.; Olajire, A.A. New ecological risk indices for evaluating heavy metals contamination in aquatic sediment: A case study of the Gulf of Guinea. Reg. Stud. Mar. Sci. 2018, 18, 44-56.

11. Müller, G. Index of geoaccumulation in sediments of the Rhine River. GeoJournal 1969, 2, 108-118.

12. Kowalska, J.B.; Mazurek, R.; Gąsiorek, M.; Zaleski, T. Pollution indices as useful tools for the comprehensive evaluation of the degree of soil contamination-A review. Environ. Geochem. Heal. 2018, 40, $2395-2420$.

13. Håkanson, L. An ecological risk index for aquatic pollution control. A sedimentological approach. Water Res. 1980, 14, 975-1001.

14. Loska, K.; Wiechuła, D.; Korus, I. Metal contamination of farming soils affected by industry. Environ. Int. 2004, 30, 159-165.

15. Sutherland, R.A. Bed sediment-associated trace metals in an urban stream, Oahu, Hawaii. Environ. Earth Sci. 2000, 39, 611-627.

16. Ho, H.H.; Swennen, R.; Van Damme, A. Distribution and contamination status of heavy metals in estuarine sediments near Cua Ong Harbo, Ha Long Bay, Vietnam. Geol. Belg. 2010, 13, 37-47. 
17. Gong, Q.; Deng, J. Calculating pollution indices by heavy metals in ecological geochemistry assessment and as case study in parks of Beijing. J. China Univ. Geosci. 2008, 19, 230-241.

18. Chai, L.; Li, H.; Yang, Z.; Min, X.; Liao, Q.; Liu, Y.; Men, S.; Yan, Y.; Xu, J. Heavy metals and metalloids in the surface sediments of the Xiangjiang River, Hunan, China: distribution, contamination, and ecological risk assessment. Environ. Sci. Pollut. Res. 2017, 24, 874-885.

19. Liu, Y.; Wang, Q.; Zhuang, W.; Yuan, Y.; Jiao, K.; Wang, M.; Chen, Q. Calculation of thallium's toxicity coefficient in the evaluation of potential ecological risk index: a case study. Chemosphere 2018, 194, 562-569.

20. Wang, N.; Wang, A.; Kong, L.; He, M. Calculation and application of Sb toxicity coefficient for potential ecological risk assessment. Sci. Total. Environ. 2018, 610, 167-174.

21. Macdonald, D.D.; Ingersoll, C.G.; Berger, T.A. Development and evaluation of consensus-based sediment quality guidelines for freshwater ecosystems. Arch. Environ. Contam. Toxicol. 2000, 39, 20-31.

(C) 2019 by the authors. Licensee MDPI, Basel, Switzerland. This article is an open access article distributed under the terms and conditions of the Creative Commons Attribution (CC BY) license (http://creativecommons.org/licenses/by/4.0/). 